\title{
THE ROLE OF LEADERSHIP IN TEACHERS' SELF-EFFICACY
}

\author{
Mirali Mammadzada \\ University of Latvia, Latvia
}

\begin{abstract}
The self-efficacy of teachers is an important aspect that must be considered in evaluating educational systems. It is affected by several factors such as teachers' professional development, motivation, and satisfaction. These factors are in turn, affected by leadership roles in the educational system. This paper aimed to determine the correlation between the role of leadership and teachers' self-efficacy through these factors. A qualitative approach was used where secondary analysis of written articles was conducted. The demographic of the sample in each journal article studied included primary, secondary, and tertiary schoolteachers in Europe. Results show that the factors under study are affected by the leadership roles of principals, school administrators, and teachers. Leadership roles improve teachers' professional development, boost motivation, and increase job satisfaction which as a result, affects the self-efficacy of teachers. Thus, the leadership roles of principals, school administrators, and teachers, particularly a transformational type of leadership in contrast with a transactional form of leadership, affect the self-efficacy of teachers positively and ultimately their performance in their classes.
\end{abstract}

Keywords: leadership roles, motivation, professional development, satisfaction, self-efficacy, teaching.

\section{Introduction}

Self-efficacy is an individual's confidence in his or her ability to perform or deal with situations to arrive at a specific goal. It is a concept that was originally initiated by psychologist Albert Bandura (1995), where he gave thought to have the belief in the capacity to exercise control over one's personal motivation, behavior, and social environment. Bandura (1995) further stated that individuals carrying out their activities are not solely driven by internal forces but are also motivated by outside factors through a chain of cognitive activities.

In the field of education, the teachers have trust in their ability to teach well. The existence of self-efficacy in teachers shows their psychological maturity thus, their belief in effectively handling tasks, obligations, and challenges play a vital role in coming up with successful academic outcomes and a better working environment. As teachers, self-efficacy is an important factor that will help ensure an improved students' learning experience. A series of research have shown that 
it is an important variable because it affects students' motivation and learning (Ma'mun \& Suryana, 2019).

The results of previous studies indicate that teaching self-efficacy is influenced by external factors such as professional development, motivation, andsatisfaction in teaching.

The research aims to show the role of leadership in the self-efficacy of teachers by determining factors affecting teachers' self-efficacy and how these factors are affected by school leadership in a qualitative analysis of related literature.

\section{Literature Review}

Teachers' self-efficacy is acknowledged to play a major part in school psychology research as shown by the effects it has on instructional practices and students' academic performance (Klassen \& Tze, 2014). It was shown that teachers with high levels of self-efficacy have also higher levels of job satisfaction. They experienced lesser job-related stress making them better equipped in handling misconducts and other related problems of students (Caprara et al., 2003). With all of these in mind, studying and understanding the beginnings of self- efficacy will make significant and crucial benefits in working and building for teachers' welfare, school effectiveness, and advancement.

\section{The Role of Professional Development in Teachers' Self-Efficacy}

A study by Yoo (2016) on the effect of teachers' professional development effort has shown that it has a beneficial impact on teachers' efficacy. Moreover, the descriptive self-analysis of teacher efficacy has revealed that acquiring new knowledge such as strength training programs was as a whole positively related to teacher efficacy. However, one finding in the study noted that participants, after having gained further knowledge or comprehension about contents and educational strategies, realized that they either overrated themselves with overconfidence or underrated themselves and having a feeling of skepticism. Consistent with Bandura's perception, the findings in this research revealed an overall positive teacher efficacy but there is a need for supplementary training that is created to assist in the teaching experience. An individual teacher's length of teaching experience does not affect the teacher's efficacy rather, it is the result of an ongoing professional development experience that increased the teacher's efficacy. 


\section{The Role of Teacher Motivation in Teachers' Self-Efficacy}

The idea of self-efficacy centers on the teachers' confidence in doing their tasks, obligations, and facing challenges effectively. This belief is resolved by several factors such as personality traits (Caprara et al., 2006). It was analyzed how a broad range of personal values such as openness and adaptability to change, the capacity to transcend oneself, and self-enhancement connected to selfefficacy, and if such relationship is checked by controlled or autonomous motivations for teaching. Control-motivated teachers conduct teaching activities for external rewards like a school official's approval or acceptance or to keep away from any guilt feelings, whereas autonomously motivated teachers carry out teaching activities because of the inherent value derived from it (Roth et al., 2007). Teachers' self-efficacy plays an important part in academic outcomes such as students' achievement and motivation. Results of the study showed that the relationships of openness to change and self-efficacy on one side and self- transcendence and self-efficacy on the other changes depending on the motivations of the teachers. The relations were stronger when teachers were aware that there was lesser external pressure and felt to be more resolved and motivated to teach which resulted in better teaching outcomes (Barni et al., 2019).

\section{The Role of Teacher Satisfaction in Teachers' Self-Efficacy}

Job satisfaction is a salient aspect in teachers' efficacy as it will increase themotivation of teachers to attain the school's objectives (Obineli, 2013). The factors of job satisfaction have been classified into two primary aspects which are extrinsic and intrinsic. It was found out that teachers with an immense feeling of self-efficacy are much unrestricted to unique thoughts and creations, manifest more dedication to educating thus improving the performance of students (Tsigilis et al., 2010). In the study investigating the relation between job satisfaction and self-efficacy by employees like teachers, several sources and instruments like the Teachers' Sense of Efficacy Scale (TSES) were used. It was found out that educational institutions must focus on enhancing the work experience and selfefficacy of teachers as well as other contributory variables that encourage teacher's job satisfaction and individual efficacy. Furthermore, various aspects ofteachers' job satisfaction are connected and have made a beneficial impact on several conditions affecting the efficacy of teachers (Gkolia et al., 2014).

From the three articles reviewed, they showed that the self-efficacy of teachers is affected by factors such as their professional development, motivation, and self-satisfaction. 


\section{Methodology Research Design}

Qualitative approach using secondary analyses of written articles was employed to conduct the analysis and interpretation of data. Taylor, et al. (2015) said that a qualitative method is appropriate to develop perceptions and understanding from patterns in the data instead of gathering data to evaluate predetermined models, hypotheses, or theories. Data was analyzed by collating relevant literature in the process of literature basis analysis method.

\section{Sampling and Procedure}

The study involved research journals from the Google Scholar database. The research journals were selected by using the keywords "factors affecting leadership role of teachers" and "factors affecting the self-efficacy of teachers". The study focused on teachers in primary, secondary, and tertiary levels situated in Europe.

\section{Mode of Analysis}

Secondary analysis was employed wherein secondary data from related literature was analyzed.

\section{Research Results}

Leadership in this study was defined as the leadership roles undertaken by principals, school administrators, and teachers.

\section{The Effect of Teachers' Leadership Roles on Their Professional Development}

Teachers see the barriers to achieving goals in processes and systems in work. With this, a decentralized decision making was implemented, supported, and found effective. This allows teachers to be leaders in school. The collaborative process enables groups to take part in leadership decisions and create a sense of ownership within organizations.

Teachers are at the center of the education system since they mold students towards success. They are leaders in each of their classes and must be provided with ample opportunities in order to upgrade personal learning and at the same time, improve the school (Schlechty, 2001). Giving teachers a chance to improve their leadership skills allows for their self-improvement, the improvement of their individual classes, and their entire school as well since it develops professionals 
that will assume administrative leadership roles later on. A strong culture in an organization must be nurtured by consistent leadership (Collins \& Porras, 1994).

The study by Hickey and Haris (2005) traversed the concept of teachers as leaders and shows findings on the effects of leadership on teachers' professional development. The research employed the practitioner research methodology that is organized at the center of the ideas of teachers as experts, cooperation with school organizations, and teacher leadership. Findings reveal that allowing teachers to present in front of their colleagues gives several benefits like increased collaboration, teamwork, and teacher leadership. Such benefits are relevant for schools. This study focused on four topics that gave the rationale for this research. First, the foundation of practitioner research was tackled to represent the basis of the research. Second, there was a discussion on teachers as experts who can provide unique perspectives to their colleagues. Third, the necessity for collaborative efforts of school organizations was directed. Lastly, the role of teachers as leaders was discussed.

The first theme that was inspected was the experience of teacher-leaders with professional development. Results show that out of 52 respondents, 33 provided positive comments, 14 were neutral, while five were constructive. With this, the majority of the teachers had positive feelings toward professional development as they share their expertise as leaders. Constructive comments were considered in improving professional development in the future. The second theme that appeared was the feedback on how teachers see leader-teachers when they share their experience on personal development. Results from interviews reveal that there was a positive impact among teachers seeing their colleagues lead in sharing information about professional development as this provides them with motivation to excel in their professional development as well. Also, teachers who have presented in front of their peers had a positive overall experience.

Though others experienced anxiety while presenting in front of their peers, the teachers saw it as an opportunity to improve their performance, increase theirsense of leadership, and focus on their professional development.

Another study by Whitworth and Chiu (2015) focused on professional development and its link to leadership. The aim of professional development in science education is to assist the learning of teachers with the eventual objective of bettering how students excel. School and area leaders have an important part in the arrangement and execution of professional development. Considering theirsignificant role, they are considered an essential element of the procedures and therefore must be taken into account as part of any developmental model in the field of science education. Being the case, leadership within the locality of the educational institution would ultimately affect student achievement (Pianta, 2011). Hence, school and district leaders must be given additional attention. 
Even though schools and districts are not the single mediators of professional development for educators, they are the primary providers (Spillane, 2002). It is essential to comprehend the perspectives of school leaders on professional development, their practices, and the aspects that impact said leaders in selecting and devising professional development. By comprehending the variables involved, it will shed light on what kind of professional development districts prefer and implement for teachers. Education leaders who take advantage of professional development may be more active in hastening the productivity of professional development for their locality.

By their involvement, they can help teachers develop professional communities, connecting teachers with materials, and advocating and supporting changes in practice. Based on this review, support should be given to district leadership to have a successful professional development program (Halverson et al., 2011).

The involvement of school leaders in professional development can also aid leaders to grasp the usefulness of the professional program, the resources required for teachers to implement the change in practice and provide them the chance to decide on how to keep up the changes needed (Spillane et al., 2001).

In a study where principals were involved in a styled program that incorporated direct intervention of experience with the investigation curricula, among others, the principals detailed that getting a grasp of the curricula and components of theprogram assisted them to identify the best support to be given to the teachers at their schools and also how to strengthen their leadership qualities (Gerard et al., 2008). The research revealed that excellent professional development is a criticalaspect of enhancing science education (Wilson, 2013). With all the proper conditions, professional development could possibly aid teachers to be more productive and may therefore proceed to improved student achievement (Yoon et al., 2007). Therefore, it is right to include the part of school and district leadershipin overseeing teacher change if people are to have a comprehensive view of the part of professional development in improving teacher and student learning in thefield of science.

\section{The Effect of Teachers' Leadership Roles on Their Motivation}

The environment of a school is demanding and has many pressures that have an effect on teachers' well-being that is usually reflected through their motivation. Research shows that if the power in learning systems is entrusted to school principals and they are trained and encouraged to be helpful to their educational employees, then these measures may possibly accelerate teachers' autonomous motivation, fulfillment, and self-esteem. Autonomous motivation has an important role in teachers' adjustment, ability to effectively learn, ability to 
effectively teach, and students' and teachers' performance and welfare, that is why it is important that motivation is studied in relation to leadership.

A study by Eyal and Roth (2011) focused on the relationship between academic leadership and teacher's motivation. It focused on two converging theories of leadership and motivation. The main hypothesis is that transformational leadership would foretell the individual motivation of teachers while transactional leadership would determine limited motivation. Moreover, it was anticipated that autonomous motivation would moderate the connection of transformational leadership and burnout of teachers and between transactional leadership and burnout.

Results show that transformational leadership was not connected with teachers' burnout, and this relationship was in part arbitrated by teachers' autonomous motivation. On the other hand, transactional leadership was positively correlated with the burnout of teachers, and this link was partially moderated by teachers' modulated motivation. With this, the style of leadership employed by the principals was seen by the teachers as a determinator of teachers' motivation along with their feelings of tiredness and fatigue.

Thus, the results imply that principals' actions play a considerable part in motivation of teachers. Also, transactional leadership which the controlling practices like monitoring subordinates and being demanding more than is properly required is linked with controlled motivations which makes teachers act due to extrinsic motivation, (Roth et al., 2009). On the other hand, transformational leadership which involves empowering of teachers is connected with autonomous motivation which allows teachers to incorporate their ideas and opinions. As a whole, this allows the overall development of teachers and their self-actualization (Bass \& Riggio, 2006).

It is essential for school principals to apply teacher-supportive leadership practices to students' learning. The study by Shepherd-Jones \& SalisburyGlennon (2018) incorporated the differing areas of educational leadership and the psychology of education in order to look into the outcomes of leadership styles of principals on teacher motivation. The outcomes of the principal leadership styles of authoritarian and laissez-faire or democratic practices on teachers' motivation were specifically probed from the methodology of the Self-Determination Theory (SDT). Findings show that leadership styles of principals, in this case, a democratic style, have given teachers a higher level of autonomy, relatedness, and competence. Moreover, administrators shared their course of action in how they aided teachers' autonomy, relatedness, competence, and other motivational methods.

There were three objectives of the study. First, the research from the merging of the different areas of educational psychology and educational leadership. Next, the relationship between the teachers' appreciation of their principals' leadership 
styles and their motivation at work were analyzed. Third, there was a merging of the results of researchers from the academe and educational leaders by summoning them to explain the real-life inferences of teacher-reported outcomesprovided from the study.

This research created a distinctive contribution by incorporating the educational leadership study with the leadership styles of authoritarian, democratic, or laissez-faire usages with educational psychological research into the psychological needs of autonomy, capability, and relatedness as identified by the Self-Determination Theory. The results of this study revealed that the way in which teachers viewed their principal's style of leadership was related to the motivation they encountered at work. The principals' perceptions had an effect on the tactics they used to boost teachers' motivation. In this case, it clearly showed that perceptions are important.

\section{The Effect of Teachers' Leadership Roles on Their Satisfaction}

The most favored discussion to assess within the structure of leadership is job satisfaction. Based on the two-factor theory of Herzberg (1966), the leadership of school administrators and the principal affect teachers' satisfaction and experiences that can either be in a good or bad way. The study by Çogaltay \& Karadag (2016) aimed to examine the outturn of educational leadership on teachers' job satisfaction using the meta-analysis method. The objective was to analyze quantitatively the relationship outcomes obtained from the study by examining the connection between educational leadership and job satisfaction. This way the findings were used in rendering more dependable choices on the propensity and strength of the relationship related results by meta-analysis.

As gleaned from the results, educational leadership play a strong positive effect on the job satisfaction of teachers. The levels of job satisfaction are high both on the external and internal factors with the exceptions of salaries and wages of teachers.

Therefore, teachers' perceptions of job satisfaction that are on top of the normal can be viewed as the cause of a large effect of leadership on job satisfaction. Furthermore, based on Maslow's Hierarchy of Needs, the selfconfidence level is immediately linked with the points of view of the school administrators (Spector \& Bruk-Lee, 2008). There is a positive connection between job satisfaction and constructive leadership behavior. On the other hand, job satisfaction has a negative correlation with destructive leadership behavior. Every research included in the study came up with the same result that the relationship between constructive leadership and job satisfaction were discovered to be positive. The study on the relationship between detrimental leadership behaviors and job satisfaction demonstrated that the correlation was negative 
using the meta-analysis method (Schyns \& Schilling, 2013).

The article by Bogler (2001) tried to discover the extent of the dissimilarity in teachers' job satisfaction that could be ascribed to their ideas of the profession in comparison to their ideas about their principals' decision-making leadership style. By using a quantitative questionnaire and path analysis to describe teacher job satisfaction by the external factors, the most important observation was that teachers' professional connotations strongly influenced their satisfaction. The principals' transformational leadership had an effect on teachers' satisfaction directly and indirectly through their professional perceptions. Outcomes of the study were tackled in relation to principals and supervisors and also to policymakers at the government level.

The conclusions of this report uphold the study performed which presented that teachers favored working with a principal who acts as a transformational leader who works with teams as opposed to that of a transactional leader or one who focuses on supervision. Transformational leadership seems to advance the autonomy that teachers have always possessed but this should also serve as a challenge for education considering that it is in the area of how teachers can improve coordinating their work that should be emphasized and not on how they maximize their autonomy which seems to be reinforcing organizational structures and functions that may be becoming outdated. The research reveals that to boost the level of job satisfaction of teachers, attention should be given to aspects related to all variables of the teaching profession. Considering that perceptions of their profession are very important in their satisfaction from the job, decision-makers from the local level up to the top level of government should acknowledge these findings. Moreover, principals in educational institutions must be more conscious of how massively their leadership roles and behaviors affect teachers' perceptions about their profession and job satisfaction.

By practicing transformational leadership and participative behavior, school principals can work out and promote positive attitudes and feelings of teachers regarding their occupation. When looking at teaching as their occupation that can give these teachers a sense of self-esteem and professional standing and consider it as an integral part of their lives, this will surely increase their satisfaction from their job.

The satisfaction of teachers derived from their job is crucial between the relationship of teachers and students, for highly satisfied teachers would give more time and energy in teaching their students. Therefore, this study may give the kickoff of the research connecting principals to teachers to students. It is vital then to gather data from the principals regarding their leadership styles, how the variables contribute to the views of teachers about their satisfaction and in the end, the students' learning experiences. This line of research is more useful these days, especially when the assumption of all the people concerned in the education 
process is more placed higher than the previous years.

From the related literature selected for study, it can be generalized that the factors professional development, motivation, and satisfaction of teachers are affected by leadership roles undertaken by principals, district leaders or administrators, and teachers. Since the self-efficacy of teachers are affected by such factors, the relationship of teachers' leadership roles and self-efficacy could be correlated. The following diagram shows the general idea for the correlation of the study.

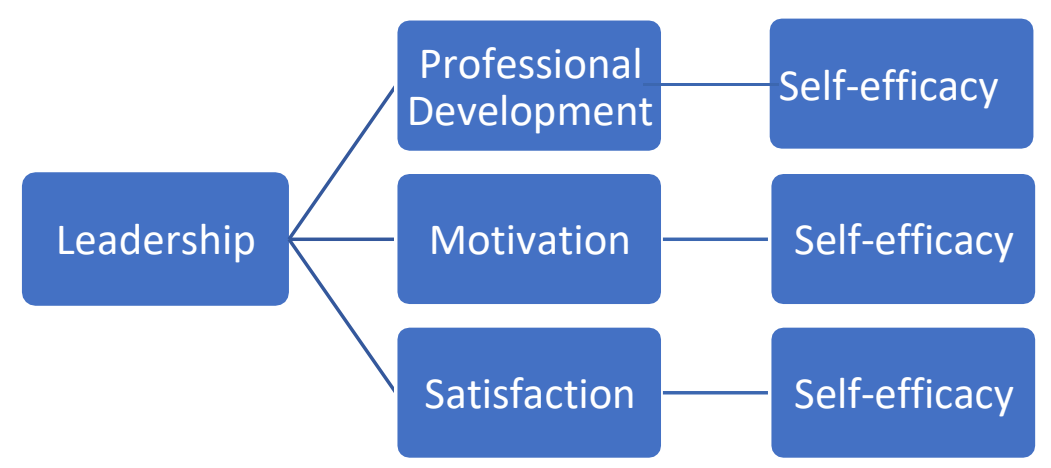

Figure 1 Generalization from the Literature Analysis

\section{Conclusions and Discussion}

Teachers' professional development, motivation, and satisfaction are factors that affect self-efficacy. These factors are subsequently affected by leadership roles in school either positively or negatively. Transformational leadership has a positive effect on professional development, motivation, and satisfaction while transactional leadership most of the time has a negative effect on these factors. From the correlation found between leadership roles in the education system and the professional development, motivation, and satisfaction of teachers, it can be concluded that leadership roles are undertaken by principals, administrators, and teachers affect the self-efficacy of teachers.

From this study, leadership functions need to be strengthened. An example is the necessity of school principals to be actively involved in helping teachers solve problems such as by providing educational advice that cannot be overlooked. Principals must also set goals where objectives are identified, and measurable goals and timeframes are established. All these goals discussed with teachers are prioritized in order to achieve higher levels of learning. This is where the essential qualities of good leadership come into play such as being trustworthy, respectful to colleagues and other school co-workers, open to the views and ideas without being judgmental, answer positively to teachers seeking feedbacks, new ideas, and methods, and other positive qualities. In order for 
school leaders to be effective, they need the support and cooperation of teachers. Teachers in turn should give them opportunities for professional development so that they can improve or increase their efficacy as leaders.

\section{References}

Bandura, A. (1995). Exercise of personal and collective efficacy in changing societies. Selfefficacy in changing societies. Self-efficacy in changing societies, 1-45.

Barni, D., Danioni, F., \& Benevene, P. (2019). Teachers' self-efficacy: The role of personal values and motivations for teaching. Frontiers in psychology, 10, 1645.

Bass, B.M., \& Riggio, R.E. (2006). Transformational leadership. Lawrence Erlbaum Associates Publishers.

Bogler, R. (2001). The influence of leadership style on teacher job satisfaction. Educational administration quarterly, 37(5), 662-683.

Caprara, G.V., Barbaranelli, C., Borgogni, L., \& Steca, P. (2003). Efficacy beliefs as determinants of teachers' job satisfaction. Journal of educational psychology, 95(4), 821.

Caprara, G.V., Barbaranelli, C., Steca, P., \& Malone, P.S. (2006). Teachers' self-efficacy beliefs as determinants of job satisfaction and students' academic achievement: A studyat the school level. Journal of school psychology, 44(6), 473-490.

Çogaltay, N., \& Karadag, E. (2016). The Effect of Educational Leadership on Organizational Variables: A Meta-Analysis Study in the Sample of Turkey. Educational Sciences: Theory and Practice, 16(2), 603-646.

Collins, J.C., \& Porras, J.I. (1994). Built to last: Successful habits of visionary companies. New York: HarperCollins Publishers.

Eyal, O., \& Roth, G. (2011). Principals' leadership and teachers' motivation: Self-determination theory analysis. Journal of educational administration.

Gerard, L.F., Bowyer, J.B., \& Linn, M.C. (2008). Principal leadership for technologyenhanced learning in science. Journal of Science Education and Technology, 17(1), 1-18.

Gkolia, A., Belias, D., \& Koustelios, A. (2014). Teacher's job satisfaction and selfefficacy: A review. European Scientific Journal, 10(22).

Halverson, R., Feinstein, N., \& Meshoulam, D. (2011). School leadership for science education. The role of public policy in K-12 science education, 397-430.

Herzberg, F. I. (1966). Work and the Nature of Man. World.

Hickey, W.D., \& Harris, S. (2005). Improved professional development through teacher leadership. The Rural Educator, 26(2).

Klassen, R.M., \& Tze, V.M. (2014). Teachers' self-efficacy, personality, and teaching effectiveness: A meta-analysis. Educational research review, 12, 59-76.

Ma'mun, M., \& Suryana, A. (2019). Instructional leadership: the effect of Teaching selfefficacy. Educational Administration Research and Review, 3(1), 35-43.

Obineli, A.S. (2013). Teachers' perception of the factors affecting job satisfaction in Ekwusigo Local Government of Anambra State, Nigeria. African Research Review, 7(4), 225-237.

Pianta, R.C. (2011). Teaching Children Well: New Evidence-Based Approaches to Teacher Professional Development and Training. Center for American Progress.

Roth, G., Assor, A., Kanat-Maymon, Y., \& Kaplan, H. (2007). Autonomous motivation for teaching: how self-determined teaching may lead to self-determined learning. Journal of 
educational psychology, 99(4), 761.

Roth, G., Assor, A., Niemiec, C.P., Ryan, R.M., \& Deci, E.L. (2009). The emotional and academic consequences of parental conditional regard: Comparing conditional positive regard, conditional negative regard, and autonomy support as parenting practices. Developmental psychology, 45(4), 1119.

Shepherd-Jones, A.R., \& Salisbury-Glennon, J.D. (2018). Perceptions Matter: The Correlation between Teacher Motivation and Principal Leadership Styles. Journal of Research in Education, 28(2), 93-131.

Schlechty, P.C. (2001). Shaking up the schoolhouse (Vol. 2). San Francisco: Jossey-Bass.

Schyns, B., \& Schilling, J. (2013). How bad are the effects of bad leaders? A meta-analysis of destructive leadership and its outcomes. The Leadership Quarterly, 24(1), 138-158.

Spector, P.E., \& Bruk-Lee, V. (2008). Conflict, health, and well-being. In C.K.W. De Dreu \& M.J.Gelfand (Eds.), The organizational frontiers series. The psychology of conflict and conflict management in organizations (p. 267-288). Taylor \& Francis Group/Lawrence Erlbaum Associates.

Spillane, J.P. (2002). Local theories of teacher change: The pedagogy of district policies and programs. Teachers college record, 104(3), 377-420.

Spillane, J.P., Halverson, R., \& Diamond, J.B. (2001). Investigating school leadership practice: A distributed perspective. Educational researcher, 30(3), 23-28.

Taylor, S.J., Bogdan, R., \& DeVault, M. (2015). Introduction to qualitative research methods: A guidebook and resource. John Wiley \& Sons.

Tsigilis, N., Koustelios, A., \& Grammatikopoulos, V. (2010). Psychometric Properties of the Teachers' Sense of Efficacy Scale Within the Greek Educational Context. Journal of Psychoeducational Assessment, 28(2), 153-162.

Whitworth, B.A., \& Chiu, J.L. (2015). Professional development and teacher change: The missing leadership link. Journal of Science Teacher Education, 26(2), 121-137.

Wilson, S.M. (2013). Professional development for science teachers. Science, 340(6130), 310-313.

Yoo, J.H. (2016). The effect of professional development on teacher efficacy and teachers' self-analysis of their efficacy change. Journal of Teacher Education forSustainability, 18(1), 84-94.

Yoon, K.S., Duncan, T., Lee, S.W.Y., Scarloss, B., \& Shapley, K.L. (2007). Reviewing the evidence on how teacher professional development affects student achievement. issues \& answers. rel 2007-no. 033. Regional Educational Laboratory Southwest (NJ1). 